\title{
LARVA, PUPA, IMAGO: PRÓBA REDEFINICJI POJĘCIA WIZERUNKU POLITYCZNEGO W UJECCIU KOMUNIKOLOGICZNYM
}

\author{
ARTUR URBANIAK
}

\section{Uwagi wstępne}

Pojęcie wizerunku politycznego związane jest nierozłącznie z rozwojem mediów masowych i stopniową profesjonalizacją kampanii wyborczych i całego życia politycznego. Wzrost znaczenia mediów jako ogniwa pośredniczącego w przekazie politycznym wymógł na elitach politycznych podniesienie kwalifikacji w obszarze komunikowania międzyosobowego, zwłaszcza zaś komunikowania za pośrednictwem mass mediów. Badacze komunikowania zwracają uwagę na symbiozę polityków z czwartą władzą, czyli środkami masowego przekazu. Jest to wynikiem urynkowienia polityki, charakterystycznego dla otwartych systemów demokratycznych. Wolny rynek oznacza konkurencję podmiotów politycznych, a ta wymaga od aktorów sceny politycznej zdobywania widoczności medialnej celem pozyskania głosów (zob. Dobek-Ostrowska, 2006: 273). Zatem zdobycie poparcia w wyborach demokratycznych w dużej mierze zależy od rozpoznawalności (widoczności medialnej) i wizerunku politycznego, czyli tego jak dany komunikator postrzegany jest przez odbiorców przekazu (wyborców).

Królowie, satrapowie, autokraci, dyktatorzy czy tyrani panujący autorytarnie nie dbali o to jak są postrzegani przez podwładnych. Natomiast współcześni politycy pretendujący do objęcia urzędów państwowych w otwartych systemach demokratycznych muszą nade wszystko zdobyć zaufanie wyborców. Obecnie komunikatora 
politycznego, określanego także mianem aktora sceny politycznej (zob. DobekOstrowska, 2006; 2009) charakteryzuje określony zespół cech, który nazywamy wizerunkiem politycznym. Samo pojęcie wizerunek (od łacińskiego imago), zgodnie z definicją należy rozumieć jako „sposób, w jaki dana osoba lub rzecz jest postrzegana i przedstawiana"1. Czasem zachodzi jednak sprzeczność między intencją nadawcy a sposobem postrzegania tegoż nadawcy przez odbiorcę. Innymi słowy, tak definiowany wizerunek polityczny stwarza szerokie pole do interpretacji przez odbiorcę, która może wcale nie pokrywać się z oczekiwaniami nadawcy. Sprzeczność ta została w naukach o komunikowaniu dokładnie omówiona już w pracy Lazarsfelda et al. (1948), w której autorzy podważyli zasadność modelu wszechmocy mediów (znanego także jako model podskórnej igły, ang. Hypodermic Needle Model). W ślad za badaczami amerykańskimi przyjmuje się, że nie można za pomocą mediów „wstrzyknąć” gotowego komunikatu do umysłu odbiorcy. Praca nad wizerunkiem politycznym jest nieprzerwanym, zaplanowanym ciągiem zdarzeń, zmierzających do wykreowania pozytywnego, spójnego obrazu w oczach odbiorców.

Pierwszoligowi politycy i partie polityczne mozolnie budują swoje wizerunki polityczne głównie w oparciu o komunikaty nadawane za pośrednictwem mediów masowych, przy istotnym wsparciu profesjonalnych agencji Public Relations. Pośrednictwo prasy, radia, telewizji oraz serwisów internetowych, a także udział opiniotwórczych „niezależnych” autorytetów oznacza, że wciąż obowiązuje zasada tyle wiemy o polityce, ile dowiemy się z mediów (por. Urbaniak, 2014: 171). Jednak dynamiczny rozwój nowych płaszczyzn komunikacji masowej, czyli portali i serwisów internetowych, które nie podlegają ścisłej kontroli określonych koncernów medialnych czy grup interesu stwarza nowe możliwości zaistnienia na scenie politycznej także komunikatorom $\mathrm{z}$ drugiego rzędu.

W świetle powyższego, przyjmuje się, że istnieją co najmniej dwa kanały komunikacji, które mogą zostać wykorzystane przez polityków do promowania się, podnoszenia swojej widoczności medialnej i tym samym pozyskiwania przychylności wyborców. Po pierwsze przez tradycyjne media o ugruntowanej pozycji na rynku politycznym, a zatem prasę, radio i telewizję oraz tzw. nowe media i po drugie przez nowe płaszczyzny komunikowania się, takie jak portale i serwisy internetowe oraz media społecznościowe. O ile w przypadku tradycyjnych mediów, ich dostępność dla aktorów sceny politycznej jest mocno ograniczona, ponieważ polityk musi zostać zaproszony do udziału w audycji lub programie, o tyle widoczność w nowych mediach zależy wyłącznie od inwencji oraz nasilenia działań przez polityka. Niektórzy aktorzy sceny politycznej, praktycznie niewidoczni w mediach tradycyjnych, zjednują sobie poparcie w nowych mediach, które odgrywają coraz istotniejszą rolę

${ }^{1}$ Definicja za Stownikiem języka polskiego, źródło: http://sjp.pwn.pl/sjp/;2579940 [dostęp: 12.02.2017]. 
w procesach demokratycznych (zob. Himelboim et al., 2012), ponieważ docierają do rzesz nowych odbiorców. Dwa najbardziej jaskrawe przykłady polityków, którzy potrafią z sukcesem wykorzystać nowe media do wypromowania się na polskiej scenie politycznej to Janusz Kowin-Mikke (eurodeputowany) oraz Paweł Kukiz (poseł, przewodniczący ruchu Kukiz '15). Nulty, Theocharis, Popa, Parnet i Benoit (2016: 430) zauważają, że wyborcy odnaleźli w Internecie przestrzeń dla obywatelskiej aktywności. Niechęć społeczeństwa do przynależności do partii politycznych nie musi oznaczać całkowitego wyłączenia się z życia politycznego i zainteresowania tym obszarem życia społecznego. Obywatele komentują, „lajkują” (od ang. like lubić, tu: popierać) i „hejtują” (od ang. hate, nienawidzić) polityków i wydarzenia polityczne, a zatem wyrażają czynne poparcie lub dezaprobatę bieżących wydarzeń. Trudno byłoby zaprzeczyć, że Internet jako „barometr poparcia” ma zatem realny wpływ na kształtowanie się procesów politycznych.

Nowe możliwości niosą z sobą nowe zagrożenia. Potencjał jaki ukryty jest w szybkim, bezpośrednim komunikowaniu się z odbiorcą za pomocą mediów społecznościowych, takich jak Twitter, Facebook czy serwisów internetowych takich jak YouTube, pociąga za sobą ogromne ryzyko popełnienia błędu, zaliczenia wpadki czy choćby popełnienia lapsusu językowego, który może później zaważyć na wizerunku polityka. Należy bowiem pamiętać, że w dobie szybkiego dostępu do informacji, co wiąże się z ogromną ilością danych przetwarzanych przez nas każdego dnia, komunikacja polityczna ma zdecydowanie charakter powierzchowny. A zatem wizerunek polityka w oczach odbiorców często budowany jest w oparciu nie tyle o rzetelną, fachową wiedzę o działalności na rzecz społeczeństwa, a raczej w oparciu o krótkie, wyrwane z kontekstu wypowiedzi, które za pomocą mediów przedostają się do świadomości odbiorców. Na wizerunek polityczny wpływają polityczne skandale, drobne przejęzyczenia i przejściowe kryzysy. Dlatego też konsekwentne podnoszenie kwalifikacji oraz poszerzanie kompetencji komunikacyjnych, rozumianych jako umiejętność wykorzystania zasobów językowych i niejęzykowych w komunikowaniu się zdecydować mogą o tym, czy polityk z danej potyczki wyjdzie z tarczą czy na tarczy.

W dalszej części artykułu zaproponowano nowy cykl rozwoju kompetencji komunikacyjnych komunikatorów politycznych oparty na cyklu życiowym motyla. Od stadium larwalnego poprzez gąsienicę do pełnego rozkwitu kompetencji komunikacyjnych w stadium imago. Zakładając, że polityk musi zaistnieć w mediach, żeby zdobyć poparcie wyborców, przyjmuje się, że musi on zbudować lub wypracować spójny wizerunek polityczny. Według autora wizerunek polityczny buduje się w oparciu o wysokorozwinięte kompetencje komunikacyjne, na które składają się zarówno elementy werbalne jak i niewerbalne komunikowania. Stąd też podejście komunikologiczne, a nie stricte językoznawcze, wydaje się najwłaściwszą perspektywą badawczą dla omawianych tu zjawisk. 


\section{Perspektywa komunikologiczna a językoznawcza w badaniach nad komunikacją polityczną}

Sformalizowane badania nad komunikacją mają ugruntowaną tradycję akademicką sięgającą lat 30-tych XX wieku (por. Sokołowski, 2010: 39). Przyjmuje się, że podstawową dziedziną akademicką tradycyjnie utożsamianą $\mathrm{z}$ prowadzeniem badań nad językiem jest oczywiście językoznawstwo. Jednak badania nad komunikacją sensu largo, włączając zarówno komunikację werbalną, jak i niewerbalną, a zatem podejście całościowe, holistyczne, transkomunikacyjne należałoby umieścić w domenie komunikologii lub nauki o komunikacji (zob. Puppel, 2008; 2011). Etymologicznie termin komunikologia wywodzi się od łacińskiego communicatio (dzie-

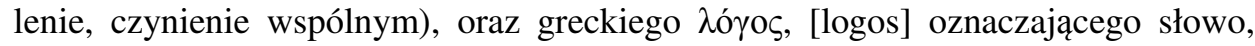
rozum, myśl. Wprowadzenie tegoż terminu przypisuje się Wendellowi Johnsonowi (1958) oraz Franklinowi H. Knowerowi (1962). Z kolei za najgorliwszych propagatorów idei stworzenia holistycznej nauki o komunikowaniu na światową skalę uważa się Viléma Flussera (1973), Josepha A. DeVito (1978) i Richarda L. Lanigana (1992). Warto odnotować, że w 2000 roku został założony Międzynarodowy Instytut Komunikologii (ICI), który zrzesza sympatyków tej dziedziny, organizuje konferencje naukowe oraz prowadzi badania empiryczne. ${ }^{2}$

Komunikologia (lub nauka o komunikowaniu) zdaje się być właściwą dziedziną do prowadzenia badań nad komunikowaniem politycznym również dlatego, że scala wszystkie dziedziny badawcze orbitujące wokół zagadnień związanych ze sposobami komunikowania się aktorów sceny politycznej z odbiorcami, otwierając przed badaczami szerokie możliwości wielowymiarowego spojrzenia na ten rodzaj komunikacji. Dobek-Ostrowska (2006: 23) zwraca uwagę na interdyscyplinarny charakter nauki o komunikowaniu, wymieniając osiem dyscyplin naukowych, z których się ona wywodzi, takich jak psychologia, prawo, politologia, socjologia, językoznawstwo, nauki techniczne, ekonomia i filozofia. To dziedziny przez pryzmat których badacze wycinkowo zajmują się komunikowaniem politycznym. Komunikologia stanowi ich wspólny mianownik. Warto odnotować, że Puppel (2008: 18-19) zwraca szczególną uwagę na praktyczny - stosowany - charakter nauki o komunikacji, wymieniając aż pięćdziesiąt obszarów badawczych, mieszczących się w zakresie zainteresowań komunikologów. Rozciągają się one od zbieżności zasobów komunikacyjnych z kontekstem sytuacyjnym, poprzez reklamę, zaburzenia $\mathrm{w}$ interakcji aż do teorii perswazji (por. Lanigan, Connolly i Craig, 2005). Syntetyzując podejście stricte lingwistyczne i komunikologiczne, przyjmuje się, że językoznawstwo i komunikologia nie wykluczają się, a jedynie ta druga stanowi szersze spojrzenie na zagadnienie komunikowania, włączając poza środkami werbalnymi również nie mniej ważne - niewerbalne.

\footnotetext{
${ }^{2}$ Więcej informacji na temat rozwoju dziedziny można uzyskać pod adresem: http://www.commu nicology.org/content/\%E2\%8C\%98-pr\%C3\%A9cis-communicology [dostęp: 13.02.2017].
} 


\section{Wizerunek polityczny a wiarygodność}

Machiavelli (1513) uważał, że większość ludzi postrzega politykę raczej w kategoriach powierzchownego, ulotnego przekazu, a nie esencji czy istoty rzeczy. Rozumieć należy to w taki sposób, że odbiorcy raczej skupiają uwagę na formie, czyli na tym w jaki sposób komunikator mówi, a nie analizują treści przekazu. Stąd też wytrawni komunikatorzy polityczni dokładają tak wiele staranności, aby sposób komunikowania się korespondował z zawartością merytoryczną komunikatu. Ponadto prekursor badań nad efektami mediów, Lipman (1922), zwrócił uwagę, że w znakomitej większości przypadków ludzie nie obcują bezpośrednio z polityką, czyli nie uczestniczą w debatach, tworzeniu prawa i ustaw, a jedynie ustosunkowują się do przekazów na tematy polityczne podanych im przez media. Warto nadmienić, że pluralizm mediów masowych oznacza dostęp do informacji interpretowanych na różne sposoby. Zawsze jednak jest to przekaz zapośredniczony przez media masowe, z uwzględnieniem rosnącej roli Internetu, a zwłaszcza mediów społecznościowych jako nośnika informacji politycznej (zob. Himelboim et al., 2012: 92-93). Warto w tym miejscu podać przykład tego, w jaki sposób media mogą wpływać

Tabela 1. Ilustracja czasu antenowego poświęconego na transmisje na żywo z wydarzeń z udziałem kandydatów na urząd prezydenta USA w 2016 roku w trzech wybranych stacjach telewizyjnych ${ }^{3}$

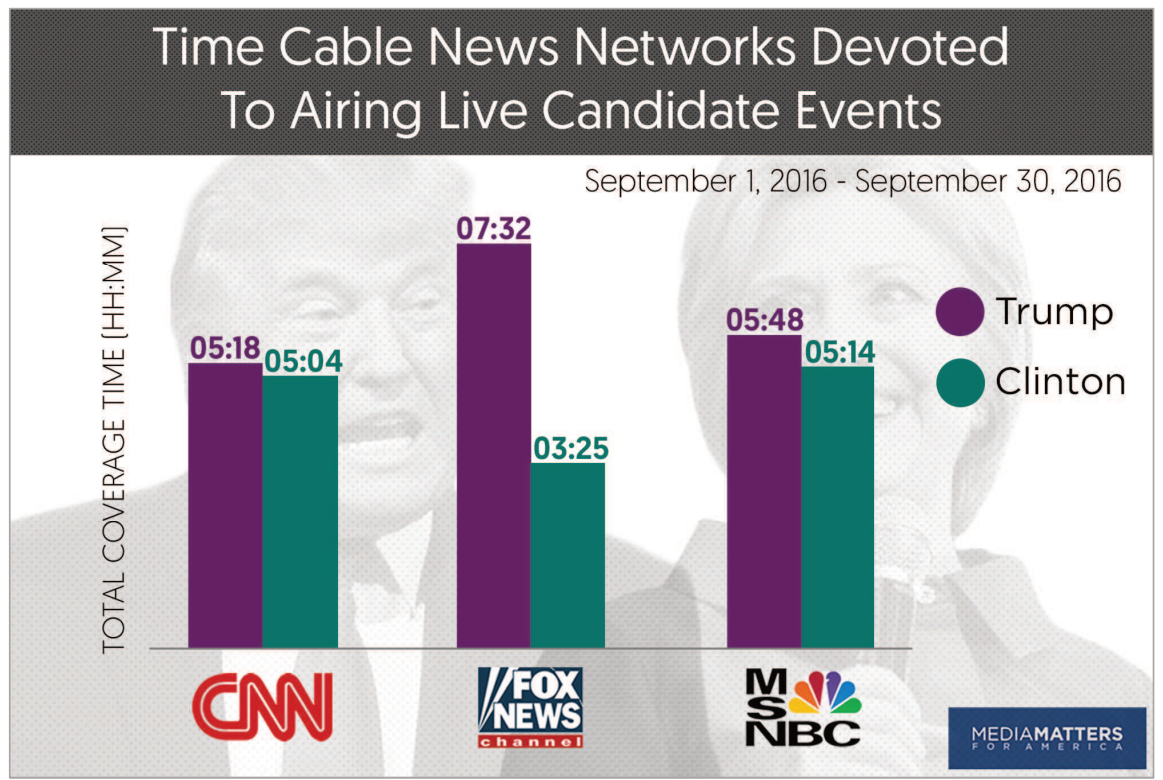

${ }^{3}$ Źródło: http://www.mediamatters.org/blog/2016/10/06/study-compared-msnbc-and-cnn-fox-news-devo tes-more-time-trump-events-and-less-time-clinton-events/213578 [dostęp: 14.02.2017]. 
i kształtować wizerunek polityka choćby poświęcając danemu komunikatorowi więcej uwagi. Badania ratingowe przeprowadzone przez Media Matters w kontekście wyborów prezydenckich w Stanach Zjednoczonych w roku 2016 pokazują jasno, że stacja Fox News poświęciła znacznie więcej uwagi kandydatowi Donaldowi Trumpowi niż kandydatce Hillary Clinton (w samym wrześniu 2016 stosunek wyniósł: 7,32 do 3,25 godz. transmisji na żywo z wydarzeń z udziałem kandydatów, włączając konferencje prasowe i wiece wyborcze). W dłuższej perspektywie czasowej, różnica ta tylko się pogłębiła (od 1. czerwca do 30. września 2016: Trump: 25,25 a Clinton: 13,52 godz. $)^{4}$.

Podobnie jak w przypadku komunikatów o treści związanej z polityką, wizerunek polityczny także jest przekazem zapośredniczonym. Przyjąć należy za Nimmo i Savagem (1976), że ,wizerunek polityczny to subiektywny konstrukt mentalny, który formuje się [w umyśle odbiorcy - przypis A.U.] w nawiązaniu do przekazu medialnego" (w: Hacker, 2008: 322). Interpretować należy to w taki sposób, że większość obywateli czerpie wiedzę o politykach z mediów, a niewiele osób zna na przykład posłów na Sejm ze swojego okręgu wyborczego osobiście. To jak wyborcy postrzegają danego polityka, zależy w dużej mierze od tego jaki obraz udało się danemu komunikatorowi zbudować w świadomości społecznej za pomocą mediów.

$\mathrm{O}$ tym jak istotną rolę w kształtowaniu wizerunku politycznego odgrywają media społecznościowe dowodzą najnowsze badania (zob. Nulty et al., 2016; Dalton i Welzel, 2014; Himelboim et al., 2012). Warto odnotować, że w nauce o komunikowaniu przyjmuje się współistnienie aktywnych i pasywnych ogniw (za: DobekOstrowska, 2006). Wyborcy przez lata zaliczani byli do ogniwa pasywnego z uwagi na to, że spadało zarówno zainteresowanie polityką, jak i zaangażowanie w politykę po stronie odbiorców. Jednak obserwuje się ożywienie aktywności obywateli. Internet, a zwłaszcza media społecznościowe zdają się pozytywnie wpływać na proces aktywizacji wyborców. Nulty et al. (2016: 430) piszą, że „kampanie wyborcze w zasadniczej części polegają na komunikacji” (tłumaczenie: A.U.), co wymusza na elitach politycznych dostosowanie się do nowych warunków i wykorzystanie nowych cyfrowych mediów. Himelboim et al. (2012: 92) sugerują, że „obywatele zyskują nowe możliwości na uczestnictwo w życiu politycznym poprzez przyłączanie się do grup zainteresowań [w mediach społecznościowych - przypis A.U.], interakcję z instytucjami politycznymi, kandydatami oraz wymianę poglądów i dyskusję na tematy polityczne z innymi obywatelami" (tłumaczenie: A.U.). Partycypacja w życiu politycznym w Internecie rośnie roku na rok. Dane przytoczone przez Himelboima et al. (2012) pokazują, że w USA w wyborach z roku 2008 aż 55\% dorosłych obywateli wykazywało jakiś rodzaj zaangażowania politycznego w mediach cyfro-

\footnotetext{
${ }^{4}$ Szczegółowy wgląd w metodologię badań i ich wyniki znajduje się pod adresem: http://www.me diamatters.org/blog/2016/10/06/study-compared-msnbc-and-cnn-fox-news-devotes-more-time-trump-eventsand-less-time-clinton-events/213578 [dostęp: 14.02.2017].
} 
wych. A w roku 2010 zaobserwowano wzmożoną aktywność w kampanii wyborczej, w której $22 \%$ dorosłych obywateli zaangażowało się politycznie na Twittterze i innych stronach społecznościowych. Analizując te dane należy skonkludować, że politycy muszą zadbać o widoczność medialną i swój wizerunek polityczny również w mediach cyfrowych, co wymaga od nich nabycia umiejętności formułowania choćby krótkich werbalnych (tekstowych) przekazów. Należy zatem przyjąć, że współczesny tarnskomuniakator, czyli komunikator w stadium rozwoju określanym imago, powinien ex vi termini korzystać ze wszystkich najnowszych urządzeń i aplikacji służących komunikacji z odbiorcami.

\section{Rozwój kompetencji komunikacyjnych: Imago}

W dobie marketingu politycznego świadomy komunikator polityczny powinien zdawać sobie sprawę z konieczności nieprzerwanego doskonalenia swojego warsztatu komunikacyjnego, czyli rozwijania swoich kompetencji komunikacyjnych, zarówno w sferze werbalnej jak i niewerbalnej. W myśl łacińskiej maksymy poeta nascitur, orator fit (poetą się rodzisz, mówcą stajesz) zawodowi komunikatorzy polityczni dostrzegli potrzebę doskonalenia w sferze komunikacji, co nietrudno zauważyć porównując choćby spoty wyborcze partii politycznych z pierwszych po drugiej wojnie światowej wolnych wyborów parlamentarnych z roku 1991 ze spotami wyborczymi z roku 2015. Spostrzec można nie tylko rozwój środków technicznych, lepszą jakość materiałów audiowizualnych, dostęp do mediów społecznościowych i innowacje w technologiach cyfrowych (zob. Nulty et al., 2016: 430), ale przede wszystkim widać zmianę w sposobie komunikowania się polityków z odbiorcami. W sferze elementów werbalnych nastąpiło wyjście ze sfery politycznego sacrum, które charakteryzowało się specyficznym skostniałym, partyjno-urzędniczym językiem, pustosłowiem, czyli mową rozwlekłą lecz pozbawioną treści (zob. Laskowska, 2004; Bralczyk, 2007). W dobie konkurencji politycznej, w otwartych systemach demokratycznych, komunikaty polityczne adresowane są do konkretnych grup odbiorców-klientów, a zatem muszą być krótsze i bardziej precyzyjne, „dopasowane" (od ang. tailored). W sferze oddziaływań niewerbalnych także daje się odczuć profesjonalizacja rynku politycznego i kampanii wyborczych. Komunikatorzy czynią użytek z całego garnituru zachowań niewerbalnych (za: Allhoff i Allhoff, 2006), takich jak gesty, postawa ciała, prozodia, dystans międzyosobowy, a także ubiór, fryzura czy odpowiedni makijaż.

Kompetencje komunikacyjne, w odróżnieniu od kompetencji językowych, to dobór środków i oddziaływań w sferze werbalnej i niewerbalnej zgodny z określonym kontekstem sytuacyjnym (por. Urbaniak, 2015: 227). Komunikator hybrydowy, transkomunikator, to polityk, który potrafi dopasować i dostosować środki wyrazu do sytuacji, w której się znajduje. Modelowa egzemplifikacja zaproponowana przez 
Puppla (2004) w pełni odzwierciedla typy komunikacyjne charakterystyczne dla komunikowania politycznego. Pierwszy typ to Oskar, wzorowany na bohaterze powieści G. Grassa „Blaszany bębenek”. Ten typ komunikatora charakteryzuje się tym, że operuje wyłącznie na najniższych zasobach językowych i niezdolny jest do wejścia na wyższy poziom komunikowania. Drugi typ, Guliwer, noszący imię bohatera powieści J. Swifta „Podróże Guliwera” posiada niezwykłe zdolności adaptacyjne i potrafi dostosować się do środowiska komunikacyjnego; raz jest duży a raz mały. Petroniusz z kolei, bohater powieści H. Sienkiewicza „Quo vadis”, stanowi przeciwległy biegun w stosunku do omówionego powyżej Oskara. Petroniusz, klasyczny retor, bazuje zawsze wyłącznie na najwyższych zasobach językowych i nie skalałby się wyjściem poza strefę językowego sacrum (zob. Puppel, 2004; Urbaniak, 2014). Omówiona tu typologia zaproponowana przez Puppla odnosi się do istniejących w przestrzeni publicznej bytów politycznych i opisuje posiadane przez nich kompetencje komunikacyjne. Spośród wymienionych typów komunikacyjnych to Guliwer wydaje się być optymalnym komunikatorem politycznym, ponieważ wykazuje najdalej rozwinięte zdolności adaptacyjne. Proponowany przez autora w dalszej części artykułu cykl rozwoju komunikatora politycznego, od larwy do imago jest niczym innym, jak dążeniem do stania się właśnie optymalnym politycznym transkomunikatorem.

Założyć należy, że celem do którego dążą komunikatorzy polityczni jest osiągnięcie takiego poziomu rozwoju kompetencji komunikacyjnych, który umożliwiłby skuteczne, wydajne i zoptymalizowane, czyli właściwe i zgodne z kontekstem sytuacyjnym komunikowanie się z odbiorcami. Taki stopień rozwoju kompetencji komunikacyjnych proponuję określić mianem stanu imago. Termin ten zaczerpnięty $\mathrm{z}$ entomologii, pochodzący od łacińskiego imago (obraz) oznacza ostateczne stadium w rozwoju osobniczym owadów. Co więcej, termin ten określa owada doskonałego, w pełni rozwiniętego, dorosłego, który nie podlega już dalszym przeobrażeniom i który to osobnik zdolny jest do rozrodu. Przenosząc terminologię z nauk przyrodniczych do nauki o komunikacji, imago to komunikator polityczny o wykształconych kompetencjach komunikacyjnych, określanych także jako kompetencje polityczne (zob. Dobek-Ostrowska, 2006: 279), które de facto są tożsame z kompetencjami komunikacyjnymi (Urbaniak, 2014: 71). Ten wysoko wykwalifikowany typ komunikatora cechują błyskotliwość, umiarkowanie, rzeczowość i racjonalność w działaniu, wykształcone na drodze doświadczenia nabytego na scenie politycznej i podczas pełnienia funkcji publicznych. Ponadto, imago posiada zdolność do inspirowania kolejnych pokoleń komunikatorów politycznych. Jest to więc stan doskonały, super politicus, najwyższe stadium rozwoju transkomunikatora.

Cykl rozwojowy owadów, w tym motyli, określany mianem holometabolia to przeobrażenie zupełne, a zatem z uwzględnieniem stadium poczwarki. Aby osiągnąć stan imago, komunikator polityczny winien przejść cykl życiowy podobny do motyla. Faza pierwsza, larva (gąsienica) to początek kariery politycznej, nierzadko zwią- 
LARVA

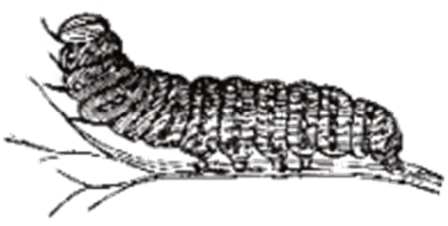

Caterpillar
PUPA

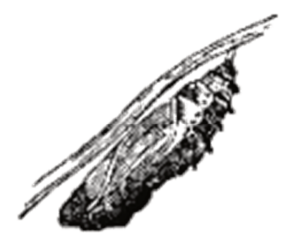

Chrysalis
IMAGO

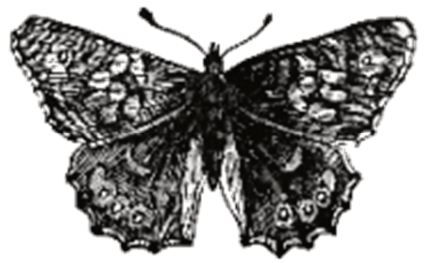

Butterfly

Rys. 1. Stadium rozwoju owada na przykładzie motyla ${ }^{5}$

zany z poszukiwaniem przez komunikatora właściwej sobie ścieżki kariery. Pod względem komunikacji w sferze elementów werbalnych, początkujący aktor sceny politycznej przejawia tendencję do pochopnego wyrażania osądów i używania językowych zasobów komunikacyjnych nielicujących z kontekstem sytuacyjnym. Stadium larwalne charakteryzuje też brak umiejętności prowadzenia sporu, uleganie niekontrolowanym emocjom, nieumiejętność prowadzenia dialogu, sięganie po ataki ad personam zamiast po rzeczowe argumenty, a nade wszystko brak umiejętności przekonywania do swojej racji. Polityk, który nie potrafi zjednać sobie zwolenników nie ma szans na powodzenie $w$ warunkach urynkowionej walki politycznej, $\mathrm{z}$ jaką mamy do czynienia w systemach demokratycznych. Taka osoba nie jest bowiem w stanie przekonać wyborców do swojego ,produktu”, czyli programu politycznego. Kolejne stadium rozwoju motyla to pupa (poczwarka). Komunikator polityczny na tym etapie rozwoju posiada pewne, ograniczone kompetencje komunikacyjne, jednak niewystarczające do zapewnienia sobie stabilnego poparcia i utorowania drogi do rozkwitu kariery politycznej. Stadium poczwarki to polityk co najwyżej drugoliniowy, potrafiący wprawdzie wyróżnić się na tle konkurencji politycznej, ale niebędący $\mathrm{w}$ stanie prowadzić polemiki politycznej $\mathrm{z} \mathrm{w}$ pełni ukształtowanym aktorem sceny politycznej. Pupa to stadium przejściowe, co oznacza, że polityk na tym etapie rozwija się, podnosi swoje kompetencje komunikacyjne i dąży do osiągnięcia stadium finalnego. Jednak stadium przejściowe nie może trwać w nieskończoność. Komunikator polityczny, który przestaje się rozwijać i nie osiąga stadium imago prędzej czy później utraci wiarygodność i zostanie zdominowany, przyćmiony i zdyskredytowany przez konkurencję polityczną. Zatem rozwój kompetencji komunikacyjnych zdaje się być imperatywem, w rozumieniu nakazu niepodlegającego dyskusji, dla komunikatorów politycznych aspirujących do najwyższych urzędów w państwie.

\footnotetext{
${ }^{5}$ Źródło: http://imagomfg.com/imago [dostęp: 12.02.2017].
} 


\section{Uwagi końcowe}

Na wizerunek polityczny komunikatora, czyli sposób w jaki postrzegany jest on przez wyborców ma wpływ wiele czynników, zarówno zależnych jak i niezależnych od samego nadawcy komunikatu. Zaproponowane w niniejszym artykule stadium imago, a zatem najwyższy etap rozwoju kompetencji komunikacyjnych komunikatora politycznego może stanowić przepustkę do kariery politycznej dla osób aspirujących do objęcia najwyższych funkcji w państwie. Przyjmuje się, że komunikator, który w pełni nie rozwinął kompetencji komunikacyjnych i nie osiągnął stanu imago, nie posiada umiejętności zjednywania sobie wyborców i nie potrafi poradzić sobie w sytuacjach trudnych i kryzysowych. Jednak wiarygodność polityka to nie tylko słowa. To także gesty i kontakt wzrokowy. Warto przypomnieć, że badania nad komunikowaniem pokazały, że jeżeli przekaz werbalny nie jest spójny z przekazem niewerbalnym to nadawca komunikatu wydaje się w oczach odbiorcy mało wiarygodny (zob. Mehrabian, 1972). Co się z tym wiąże, polityk taki ponosi straty wizerunkowe, które mogą kosztować go nawet utratę urzędu. Praktyka komunikacyjna pokazuje, że na wizerunku politycznym mogą zaciążyć nawet błahe, pozornie nieistotne wydarzenia, pomówienia czy bezpodstawne oskarżenia, jeśli komunikator polityczny nie potrafi się z nimi zmierzyć. Wniosek nasuwa się sam: nieumiejętne wykorzystywanie zasobów komunikacyjnych może w prosty sposób prowadzić do utraty wiarygodności w oczach wyborców. A utrata wiarygodności może przekładać się na spadek poparcia wyrażony przy urnach wyborczych.

Debata polityczna może przesądzić o wyniku wyborów. Ten komunikator, który będzie lepiej przygotowany do prowadzenia dysputy ma większe szanse na zyskanie przychylności wyborców. Poza przygotowaniem merytorycznym, znajomością wymiernych liczb, faktów w polityce liczą się subiektywne - niemierzalne - wrażenia. Imago to komunikator, który dzięki w pełni rozwiniętym kompetencjom komunikacyjnym potrafi wpływać na wyborców, przekonywać ich do swojej racji, zapanować nad tokiem rozmowy, kiedy trzeba, umie zaatakować rozmówcę w sposób kulturalny a dotkliwy i zawsze wychodzi z potyczek słownych z tarczą, a nie na tarczy.

\section{Bibliografia}

Allhoff, D.W. i W. Allhoff. 2006. Rhetorik und Kommunikation: ein Lehr- und Übungsbuch. Monachium: Reinhardt.

Bennett, W.L. i S. Iyengar. 2008. „A new era of minimal effects? The changing foundations of political communication". Journal of Communication 58. 707-731.

Boulianne, S. 2009. „Does internet use affect engagement? A meta-analysis of research”. Political Communication 26. 193-211.

Bralczyk, J. 2007. O języku propagandy i polityki. Warszawa: Wydawnictwo Trio. 
Dalton, R. i C. Welzel. 2014. The civic culture transformed: from alegiant to assertive citizens. Nowy Jork: Cambridge University Press.

DeVito, J.A. 1978. Communicology: an introduction to the study of communication. Nowy Jork: Harper and Row Publishers.

Dobek-Ostrowska, B. 2009. Porozumienie czy konflikt? Politycy, media i obywatele $w$ komunikowaniu politycznym. Warszawa: Wydawnictwo Naukowe PWN.

Dobek-Ostrowska, B. 2006. Komunikowanie polityczne i publiczne. Warszawa: Wydawnictwo Naukowe PWN.

Dobek-Ostrowska, B. (red.). 2003. Media masowe w systemach demokratycznych. Teoretyczne problemy i praktyczny wymiar komunikowania politycznego. Wrocław: Dolnośląska Szkoła Wyższa Edukacji Towarzystwa Wiedzy Powszechnej.

Druckman, J.N. i T.J. Leeper. 2012. „Learning more from political communication experiments: pretreatment and its effects". American Journal of Political Science 56.4. 875-896.

Gibson, R. 2013. „Party change, social media and the rise of 'Citizen-initiated' Campaigning”. Party Politics. 21.2. 183-197.

Hacker, K. 2008. „Political image”. W zbiorze: Kaid, L.L. i Ch. Holtz-Bacha (red.). Encyclopedia of political communication. 322-325.

Himelboim, I., Ruthann Weaver, L., Tinkham, S.F. i K.D. Sweetser. 2012. „Social media and online political communication: the role of interpersonal informational trust and openness". Journal of Broadcasting and Electronic Media 56.1. 92-115.

Kaid, L.L. i Ch. Holtz-Bacha (red.). 2008. Encyclopedia of political communication. Tom 1 i 2. Londyn: Sage Publications Inc.

Lanigan, R.L. 1992. The human science of communicology: a phenomenology of discourse in Foucault and Merleau-Ponty. Pittsburgh: Duquesne University Press.

Laskowska, E. 2004. Dyskurs parlamentarny w ujęciu komunikacyjnym. Bydgoszcz: Wydawnictwo Akademii Bydgoskiej.

Lazarsfeld, P., Berelson, B. i H. Gaudet. 1948. The people's choice: how the voter makes up his mind in a presidential campaign. Nowy Jork: Columbia University Press.

Lippmann, W. 1922. Public opinion. Nowy Jork: Macmillan.

Machiavelli, N. 1513/1964. The prince. Nowy Jork: St. Martin's Press.

Mehrabian, A. 1972. Nonverbal communication. Chicago: Aldine-Atherton Publishing Co.

Nimmo, D. i R.L. Savage. 1976. Candidates and their images: concepts, methods, and findings. Pacific Palisades, CA: Goodyear.

Nulty, P., Theocharis, Y., Popa, S.A., Parnet, O. i K. Benoit. 2016. „Social media and political communication in the 2014 elections to the European Parliament”. Electoral Studies 44. 429-444.

Puppel, S. 2016. „Kuźnia Hefajstosa czyli krótki zarys teorii wizerunku w komunikacji człowieka”. Scripta Neophilologica Posnaniensia XVI. 109-124.

Puppel, S. 2011. „The universal natural language preservation mechanism: an ecological approach”. W zbiorze: Puppel, S. (red.). Transkomunikacja. W stronę sprofilowania przestrzeni publicznej jako wielopłaszczyznowej przestrzeni komunikacyjnej. Poznań: Katedra Ekokomunikacji UAM. 91-99.

Puppel, S. (red.). 2011. Transkomunikacja. W stronę sprofilowania przestrzeni publicznej jako wielopłaszczyznowej przestrzeni komunikacyjnej. Poznań: Katedra Ekokomunikacji UAM.

Puppel, S. 2008. „Communicology: remarks on the reemergence of a paradigm in communication studies”. W zbiorze: Puppel, S. i M. Bogusławska-Tafelska (red.). New pathways in linguistics 2008. $11-22$.

Puppel, S. i M. Bogusławska-Tafelska (red.). 2008. New pathways in linguistics 2008. Olsztyn: Uniwersytet Warmińsko-Mazurski. 
Urbaniak, A. 2014. Rola elementów werbalnych i niewerbalnych $w$ komunikacji politycznej końca XX i poczatku XXI wieku na podstawie analizy wybranych wystapień medialnych polskich polityków. Poznań: Katedra Ekokomunikacji UAM.

Urbaniak, A. 2016. „Kompetencje komunikacyjne: czy polska scena polityczna jest gotowa na swojego Jesse 'the Body' Venturę?". The Journal of Linguistic and Intercultural Education (JoLIE) 9.2. 193-205. 